\title{
The investigation into the influence of the features of furniture product design on consumers' perceived value by fuzzy semantics
}

\author{
A.S. Lee * \\ Associate Professor, Department of Wood-Based Materials and Design, National Chiayi University, \\ No.300 Syuefu Rd., Chiayi City, Taiwan 60004, R.O.C. \\ sheng1887@mail.ncyu.edu.tw
}

\begin{abstract}
This study employed fuzzy theory to investigate the influence of the features of furniture product design on the fuzzy semantics of Taiwanese consumers' perceived value in new product design and development in hopes of providing product designers or developers with a reference to new product design and development. Furniture designers or manufacturers can use $u(x)$, the fuzzy membership function value of the model for investigating the fuzzy semantic relation between the features of furniture product design and consumers' perceived value, to evaluate the fuzzy semantics of consumers' perceived value, and they can also employ the fuzzy semantic mean equation, namely Fuzzy Semantics Mean $=\left[\sum_{1}^{n}(a+2 b+c)\right\rfloor / 4 N$, to transform the research data into fuzzy semantics.
\end{abstract}

In this study, all the consumers agreed that the features of furniture product design were significantly correlated to the fuzzy semantics of consumers' perceived value. In terms of the fuzzy semantics of the perceived value, the consumers with different genders, ages, education backgrounds, and incomes had different opinions about the features of furniture product design, and there were significant differences between the variables. In short, this study is helpful to understand consumers' demand for products as well as the development of consumer-oriented products, enhance their purchase intention, and improve corporate performance and market competitiveness.

*To whom all correspondence should be addressed.

\section{Research background and motives}

Due to consumers rapidly changed demand in the environment full of drastic competition, so consumers' demand and the value of furniture products were very important to enterprises when they were performing furniture product design, development, and marketing. Adner and Levinthal (2001) mentioned that product development becomes a way of maintaining product value. Zedtwitz and Gassmannb (2002) stated that products enterprises with an important R\&D department are either in a strong dominant design position in its main technologies or their principal market is helpful to fit consumer's demand and satisfaction. They also pointed out that technologyoriented R\&D product development departments will be employed to develop new products. Product market and consumer's demand will influence research, technology, and product development. Hence, Zedtwitz's and Gassmannb's study is to focus on how technology-oriented R\&D product development departments to transform marketing-oriented in order to fit consumer's demand and consumers' perceived value. Therefore, contemporary enterprises should change concepts of their technology-oriented product development concepts into marketing-oriented product development concepts. Enterprises should understand consumers' preference and demand for furniture products as well as the methods for customer-based and market-based product development. Since new product development and design are closely related to consumers' behavior, enterprises should increase consumers' purchase intention by enhancing their perceived value of products in order to achieve the corporate management goals and advance their market competitiveness.

Janikow (1998) motioned that most studies on the framework of this fuzzy semantic theory to existing methodologies has concentrated only on emerging fields such as artificial neural networks (ANNs) and genetic algorithms( GAs). Janikow's study is to combine artificial neural networks (ANNs) and genetic algorithms (GAs) into fuzzy semantics, with its close reasoning capabilities, and symbolic decision trees while preserving advantages of both: uncertainty handling and gradual processing of the former with the popularity and comprehensibility. Hence, fuzzy semantics is more advantage, advancement, and reasoning capabilities to examine the influence of the features of furniture product design on consumers' perceived value in new product design development than artificial neural networks (ANNs) and genetic algorithms (GAs) in this study. Aiming at the fuzzy data in the decision-making process of design, Goumas and Lygerou (2000) brought up the fuzzy decision expansion models of PROMETHEE, or Preference Ranking Organization Method for Enrichment Evaluation, for sorting design decisionmaking projects. Fuzzy semantic evaluations were applied to all of those integration decision-making models, and the obtained fuzzy semantic results were provided for furniture product designers as references in order to establish furniture product design which satisfies consumers' demand. 
Therefore, from product strategies and concepts to development, the key points of product design should cater to consumers' preference, which is an important competitive advantage and strategy for enterprises in product differentiation.

In this study, fuzzy theory was employed to conduct an integration investigation on the influence of the features of furniture product design on the fuzzy semantics of Taiwanese consumers' perceived value in new product design and development in hopes of providing product designers or developers with references to new product design and development and introducing the correlation between the features of furniture product design and the fuzzy semantics of consumers' perceived value into the planning and marketing stages of product design. In addition, fuzzy theory was applied to the features of furniture product design to investigate the fuzzy semantic models of Taiwanese consumers' perceived value and provide enterprises with the basis for new furniture product design and development in order to advance the performances of enterprises in new product development and design.

\section{Research purposes}

This study was aimed to examine the influence of the features of furniture product design on the fuzzy semantics of Taiwanese consumers' perceived value in new product design and development as well as the differences caused by demographic variables between the features of furniture product design and the fuzzy semantics of consumers' perceived value in hopes of providing the research result for product designers as a reference. Designers are the bridge between products and users, and the matching role that they play is helpful for product designers or developers to understand the messages for demand, which customers would like to convey, to further satisfy the consumers' demand and enhance their purchase intention. Enterprises will thus create and convey the product value. Based on the aforementioned research motives and background, the research purposes are listed as follows:

- Investigating the relationship between the features of product design and the fuzzy semantics of consumers' perceived value by using fuzzy theory.

- Investigating the influence of the different backgrounds of consumers on the features of product design and the fuzzy semantics of the consumers' perceived value.

\section{Research limitation}

This study was designed to explore the fuzzy semantics of Taiwanese consumers' perceived value on the features of product design mainly from the aspect of using furniture products. The product design was focused on furniture products in this study, which was also one of the limits of this study. Furthermore, consumers in the warehouse stores in Taiwan were randomly sampled in this study.

\section{Literature review Product design features}

Design indicates that consumers' demand for the overall features of a product is expressed in the appearance, functions, characteristics, and problem solutions of the product. When design is conducted, the functions, appearance, materials, technology, specifications, and quality of a product should be considered. Nussbaum (1988) addressed that product design is a creative strategy which helps enterprises gain predominance in market competition.

Hsiao and Chen (2010) proposed nine features of product design that include color, delicacy, biomimetics, association, unreasonable combinations, narrative, symbolic symbols, operation procedures, and shaping and operation. The nine features of product design influence judgment on pleasant images, which are further divided into three categories, respectively shaping elements (color, delicacy, and biomimetics), emotional elements (association, unreasonable combinations, narrative, and symbolic symbols), and operational elements (operation procedures, shaping and operation). Chen (2010) argued that the compositional and measuring elements of product features include (1) distinction: the size, shape, color, and texture of a product, (2) integration: the arrangement of keys and the combination of colors, and (3) interaction: responses to users' feedback and intuitive operation.

If enterprises could employ the trend of consumers' demand and preferences in new product design and development when they design and develop them, they will not only save development cost but also extend the product life cycle, or PLC (Tsai, Chang \& Wang, 2003). Therefore, product design is a critical element for deciding market success, which not only attracts consumers' attention and clearly communicates with them but also enhances product value and makes consumers perceive positive value from all products.

\section{The fuzzy semantics of consumers' perceived value}

Through trades, consumers conduct an overall effectiveness assessment of perceived sacrifice and the obtainment of perceived benefits. The aforementioned viewpoint is to explain the fuzzy semantics of consumers' perceived value (Dodds \& Monroe, 1985). Bowen, Lai, and Bahler (1992) stated that as in classical logic, the truth of a sentence in fuzzy logic and fuzzy semantics is based on the interpretation of consumer's perceived value in the sentence of the survey for exploring the features of product design by consumers' using product experience. In relevant research, such as by Kacprzyk, Fedrizzi and Nurmi (1992), problems related to fuzzy semantic measurement were focused on fuzzy theory introduced to investigate the fuzzy semantics of consumers' perceived value. Engel, Blackwell and Miniard (2001) considered that perceived value indicates the difference between the time, money, physical strength, and other resources that consumers pay for a product as well as the benefits that the consumers obtain. Chen and Dubinsky 
(2003) addressed that perceived value results from the sum of trade cost as well as the value of expected benefits or loss. According to Ravald and Gronroos (1996), the concept of consumer value has become a differentiation tool and one of the critical factors to maintain corporate predominance in competition. In addition, Woodruff (1997) argued that the fuzzy semantics of consumers' perceived value is actually one type of consumers' perceived evaluation of product preferences, product attributes, attributive performance, and goal achievement; it is consumers' feeling of value for a product before they purchase the product.

Zeithaml (1988) considered that consumers' perceived value is the value perceived by customers as well as their overall evaluation for the effectiveness of a product after pay and gain, and when the gain is greater than the pay, a product will provide customers with higher value. Hence, product designers should feel consumers' preferences and demand for product attributes in order to design a product that consumers love and increase consumers' perceived value, and consumers will thus be willing to purchase the product. The correlation between consumers' perceived value and the demand for the features of product design among the consuming behavior models is thus clearly understood through the aforementioned research.

\section{Fuzzy theory}

Zadeh (1965), a professor emeritus of computer science at the University of California, Berkeley in U.S.A., brought up the theory of fuzzy sets, which expands the relationship between elements and sets in the classical set theory. In fuzzy theory, membership functions are used to express the relationships between elements and sets. A great number of practical problems are full of uncertainty and imprecision, so fuzzy concepts are quantified by the theory of fuzzy sets brought up by Zadeh (1965) mainly to deal with some research objects' mental feelings which are fuzzy and cannot be dealt with by the "either this or that" binary logic. The "either this or that" relationship does not certainly exist in some phenomena, so elements' degree of membership to sets is expanded to any value in a single interval $(0,1)$. Relevant literature on the application of fuzzy theory in product design included the researches that $\mathrm{Wu}$ (2010) employed fuzzy theory to explore product design and multichoice goal planning on marketing behavior; Wei (2003) utilized fuzzy theory for decision making in early stage of product design in order to increase market share; Tang (2009) used fuzzy theory to design concept of creative product development so as to fit consumers' needs and behavior; and $\mathrm{Su}$ (2007) employed fuzzy theory to explore product design to influence consumers' perceived value from consumers' behavior in the market.

\section{Fuzzy semantics}

Chen and Hwang (1992) mentioned eight common fuzzy semantic variables, which are great contribution to following related research. Costs, Maranon, and Cabrera (1994) as well as Hesketh, Pryor, Gleitzman and Hesketh
(1988) designed fuzzy scales as the basis of attitude measurement and developed applicable measurement tools. Chen, Wang and Chiu (2000) brought up a method for calculating the membership values of fuzzy sets, which is effective in estimation and efficient in cost-saving. Voxman (2001) classified the canonical representations of discrete fuzzy values into two categories and respectively proposed the computing methods. Matarazzo and Munda (2001) brought up integration methods for calculating fuzzy values since traditional research on semantic decisions was all confined to triangular fuzzy numbers.

Herrera, Lopez, Mendana, and Rodriguez (2001) investigated solutions for linguistic decision models and brought up the genetic method for linguistic biobjective fitness functions. Carlsson and Fuller (2000) explored the key to weighted aggregations and established a feasible solution for the process of weighted messages of importance.

The fuzzy numbers commonly used in research include: triangular fuzzy number, trapezoidal fuzzy number, and normal fuzzy number. Triangular fuzzy numbers with a semantic scale of five levels and fifty equal portions were used to display index weights in this study. Zadeh (1965) pointed out that the whole fuzzy semantic scale and fuzzy numbers can be used to explain the relationship between potential features and the membership of semantic terms from the feelings of the participants. Fuzzy numbers (from 0 to 5) could easily calculate feelings of the participants from their demand and the value of furniture products of furniture products. Goldberg (1989) stated that genetic algorithms (GAs) need spend more time making binary code for performing the parameter optimization techniques on the issues of ill-behaved problem and highly non-linear spaces. Fant and Pamela (1992) pointed out that artificial neural networks (ANNs) consist of a collection of simple nonlinear computing elements whose inputs and outputs are tied together to form a network. Recently, due to increase of the computational speed, artificial neural networks (ANNs) have also been administered in many fields, e.g., image processing, forecasting, and control. Hence, the study employed fuzzy semantics to get survey data for examining the influence of the features of furniture product design on the fuzzy semantics of Taiwanese consumers' perceived value in new product design and development. In other words, fuzzy semantics is more suitable and convenient than genetic algorithms (GAs) and artificial neural networks (ANNs) to analyze survey data for exploring the influence of the features of furniture product design on the fuzzy semantics of Taiwanese consumers' perceived value in new product design and development in the study. Based on the aforementioned fuzzy semantic aspects, the fuzzy scale and the method of writing fuzzy numbers were designed to obtain the feelings of the participants. In this study, fuzzy theory was employed to investigate the relationship between the features of furniture product design and the fuzzy semantics of consumers' perceived value. 


\section{The meaning of fuzzy theory and fuzzy numbers}

Fuzzy theory was brought up by Zadeh (1965). When it is applied to semantic measurement, the methods are usually represented by fuzzy numbers. Excluding the fuzziness of research subjects is presupposed in traditional sciences whereas the fuzziness of research subjects and the fuzzy semantics of participants on products are recognized in fuzzy theory. Several are commonly used. The membership functions and the functional figures are illustrated as follows:

\section{Triangular Fuzzy Number}

As for the entire fuzzy semantic scale, fuzzy numbers can be used to describe the relationship between potential features and the membership of semantic terms. The relationship of the fuzzy semantic figure is illustrated as follows, as shown in Figure 1\&2:

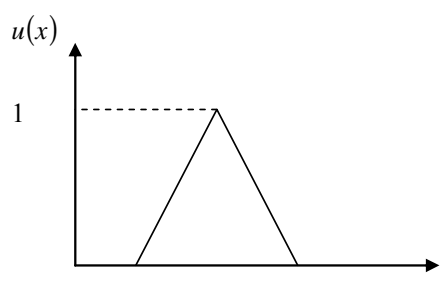

$$
u(x)=\left\{\begin{array}{ccc}
0, & x \in[0, a] \\
x-a & , & x \in(a, b) \\
1, & x=b \\
c-x, & x \in(b, c) \\
0, & x \in[c, \infty]
\end{array}\right.
$$

a $\quad$ b $\quad c \quad x$

Figure 1: Triangular fuzzy number and the membership function figure

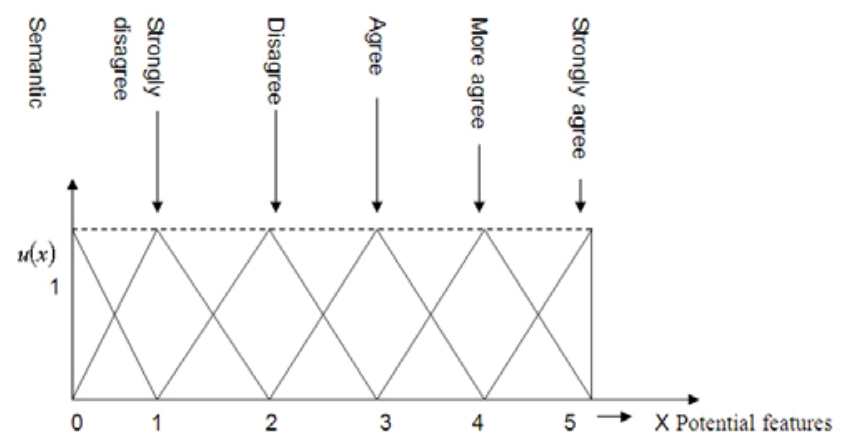

Figure 2: Using fuzzy numbers to describe the relationships between potential features and the membership of semantic terms

\section{Questionnaire data processing and fuzzy semantic statistics}

The fuzzy semantics of Taiwanese consumers' perceived value resulting from the features of furniture product design in this study belong to human psychological cognition, which is fuzzy, subjective, and uncertain. Hence, it is difficult to reasonably describe the differences and fuzziness expressed by human semantics by using a five-point Likert scale, namely using 5 to represent "strongly agree," 4 for "more agree," 3 for "agree," 2 for "disagree," and 1 for "strongly disagree," to represent the semantic terms answered by the participants. Therefore, the fuzzy semantic scale for the questionnaire in this study was divided into five levels. Fuzzy theory was first employed to process the fuzzy semantic data of Taiwanese consumers' perceived value resulting from the features of furniture product design, and relevant research analyses were then conducted. According to Klir and Yuan's (1995) complete framework of fuzzy system, the entire fuzzy process includes four steps: (1) fuzzification mechanism (data input); (2) fuzzy rules (data processing); (3) fuzzy inference engine (fuzzy inference); (4) defuzzification mechanism (data output). The steps of the fuzzy process are detailed as follows:

Step 1 (fuzzification mechanism): Triangular fuzzy numbers were used to represented the semantic variables of expectations and actual feelings in the fuzzy semantics of Taiwanese consumers' perceived value resulting from the features of furniture product design. A great number of researchers and scholars, such as Chien and Tsai (2000), $\mathrm{Wu}$, Hsiao and Kuo (2004), and Hsu and Lin (2005), employed triangular fuzzy numbers to represent semantic variables, so they were used in this study accordingly.

Step 2 (fuzzy rules): Triangular fuzzy numbers were respectively attached to the five semantic terms, including "strongly agree," "more agree," "agree," "disagree," and "strongly disagree," which were the semantic variables of expectations. " $A$ " represented a triangular fuzzy number while $X=(0,0,1),(0,1,2),(1,2,3),(2,3,4)$, and $(3,4,5)$ represent the five semantic terms respectively. The membership function figure is shown in Figure 2. Furthermore, triangular fuzzy numbers were also respectively provided to the five semantic terms of actual feelings, including "strongly agree," "more agree," "agree," "disagree," and "strongly disagree."

Step 3 (defuzzification): The statistics resulting from fuzzy computation were defuzzified to obtain specific values for further research. The defuzzification was conducted by the method of Center of Area, or CoA, used by Kaufmann and Gupta (1991), Chien and Tsai (2000), and Hsu and Lin (2005). The triangular fuzzy numbers are detailed in Figure 3:

The defuzzification formula of $\tilde{X}$ is as follows:

Suppose $\tilde{X}=(a, b, c), V_{\tilde{x}}=(a+2 b+c) / 4$,

From the fuzzy descriptive statistic equation for the second part of the fuzzy semantic questionnaire, the following equation was deduced: (1): $\tilde{X}=(a, b, c)$, and $V_{\tilde{x}}=$ $(a+2 b+c) / 4$ was transformed into

Fuzzy Semantics Mean $=\left\lfloor\sum_{1}^{n}(a+2 b+c)\right\rfloor / 4 N$, $N=723$ (the number of the participants).

From the fuzzy descriptive statistic equation for the third part of the fuzzy semantic questionnaire, the following equation was deduced: (2): $\tilde{X}=\left(a_{1}, b_{1}, c_{1}\right)$, and $V_{\tilde{x}}=\left(a_{1}+2 b_{1}+c_{1}\right) / 4$ was transformed into 
Fuzzy Semantics Mean $=\left[\sum_{1}^{n}\left(a_{1}+2 b_{2}+c_{3}\right)\right] / 4 N$, $N=723$ (the number of the participants)

The fuzzy semantic value of the questionnaire was calculated through Equations (1) and (2).

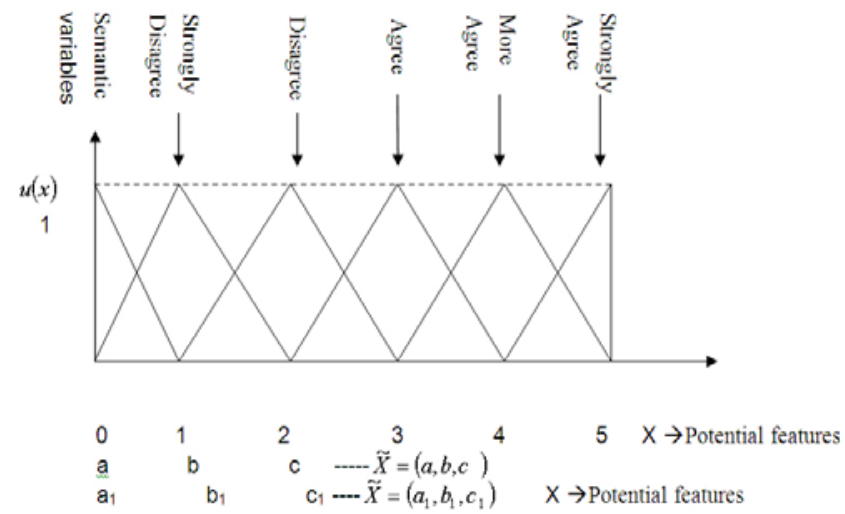

Figure 3: The membership function figure of five-level semantic variables

\section{Semantic terms}

To measure the potential characteristics of the participants, the words of options with various degrees of responses were applied to the questions of the scale to express the perception of the question. The words of options are called semantic terms, which usually consist of adverbs and adjectives and are used to express human mental perception. For example, the five fuzzy semantic terms in the five-level and fifty-equal-part scale of this study were "strongly agree," "more agree," "agree," "disagree," and "strongly disagree." Fuzzy semantic scales and Likert's scales were researched and analyzed (Lin, 2003; 2004), but there was not any comparison between the survey conformity of the interviewees' perceptions of survey questions as well as the application of the primary survey data to decision improvement. For each evaluation item, an appropriate statement of judgment was selected. Fuzzy evaluation methods were used, and fuzzy modes were calculated, so that the opinions of the majority were expressed. If there are difficulties among the evaluation results, fuzzy evaluation can be used to calculate the mean of the fuzzy semantics of consumers' perceived value, which can provided for furniture designers and manufactures as a reference to new product development.

\section{Research methodology}

\section{Research design}

\section{Research framework}

This study was aimed to investigate the relational model of the "product design features" of furniture products and the "fuzzy semantics of consumers' perceived value" and the differences between the fuzzy semantics of the perceived values of the consumers with different backgrounds in terms of product design features, the research framework as shown in Figure 4.

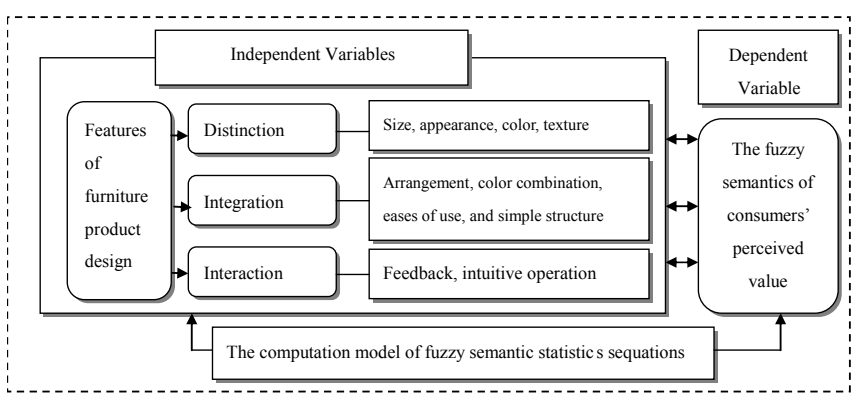

Figure 4: The relational model of the "product design features" of furniture products and the "fuzzy semantics of consumers' perceived value"

\section{Hypothesis}

$H_{1}$ : The fuzzy semantics of consumers' perceived value are significantly influenced by different features of furniture product design.

$H_{1}-1$ : The fuzzy semantics of consumers' perceived value is significantly influenced by "distinction."

$H_{1}$-2: The fuzzy semantics of consumers' perceived value is significantly influenced by "integration."

$H_{1}$-3: The fuzzy semantics of consumers' perceived value is significantly influenced by "interaction."

$\mathrm{H}_{2}$ : The features of furniture product design cause differences among the fuzzy semantics of the perceived values of different consumers.

$\mathrm{H}_{2}-1$ : The features of furniture product design cause differences among the fuzzy semantics of the perceived values of consumers with different genders.

$\mathrm{H}_{2}-2$ : The features of furniture product design cause differences among the fuzzy semantics of the perceived values of consumers with different ages.

$\mathrm{H}_{2}$-3: The features of furniture product design cause differences among the fuzzy semantics of the perceived values of consumers with different education backgrounds. $\mathrm{H}_{2}-4$ : The features of furniture product design cause differences among the fuzzy semantics of the perceived values of consumers with different incomes

The operational definitions and measurements of research variables

a. Product design

The relationships between the features of furniture product design and the fuzzy semantics of consumers' perceived value were investigated in this study. To summarize the aforementioned literature, Chen's (2010) three product 
design features, respectively distinction, integration, and interaction, were used as the major research dimensions in this study. In addition, "ease of use" and "simple structure" were added to measure furniture products. The operational definitions and measurement are detailed as follows:

- Distinction: the size, appearance, color, and texture of a product.

- Integration: arrangement, color combination, eases of use, and simple structure.

- Interaction: feedback for users and intuitive operation.

\section{b. The fuzzy semantics of consumers' perceived value}

Lin (2011) addressed that consumers' perceived value is an important factor for customers to decide whether to purchase a product or not. After the aforementioned literature was summarized, Zeithaml's (1988) opinion was adopted in this study, in which the fuzzy semantics of consumers' perceived value is the value perceived by consumers as well as consumers' overall evaluation of product efficacy after pay and gain. The "overall evaluation" indicates the difference between the pay and gain that customers perceive. When the gain is greater than the pay, the value provided by a product for customers is higher. This was employed as the operational definition and measurement of the fuzzy semantics of consumers' perceived value in this study.

\section{c. Demographic variables}

Korgaonkar, Lund, and Price (1985) brought up the causeeffect structural model and argued that demographic variables, such as age, income, and race, influence consumers' purchase behavior. Kotler (1998) classified demographic variables into ten categories, respectively age, education, the number of family, occupation, religion, family life cycle, income, nationality, and ethnic origin. Since this study was focused on the influence of product design features and the fuzzy semantics of consumers' perceived value in furniture products, the demographic variables were divided into four variables, namely gender, age, education background, and income.

\section{Research object}

Furniture products and consumers' lives are closely related. Hence, the features of furniture product design were regarded as the research scope. Moreover, consumers in the warehouse stores were randomly sampled in this study. In total, 723 copies of questionnaire were analysed.

\section{Questionnaire design and execution}

In this study, fuzzy theory was applied to the questionnaire survey, and a fuzzy semantic scale was used to replace Likert's scale to understand the fuzzy questions resulted from the mental feelings of the participants. Relevant literature was reviewed and summarized for the operational definitions of the variables and the rules of questionnaire measurement in this study. The expert panel was interviewed in order to confirm the questionnaire semantics. In addition, 102 copies of the questionnaire were pre-tested, and the questionnaire was then appropriately modified and adjusted. According to the standard that Nunnally (1995) suggested, when Cronbach's $\alpha$ is higher than 0.7, the reliability of a research questionnaire is regarded as good. Consequently, the questionnaire was formally delivered. The questionnaire included three parts. The first part was about personal background and information, including the gender, age, education background, and income of each participant. The second part was about the participants' opinions and evaluation on the features of furniture product design, including distinction, integration, and interaction. The third part was about the fuzzy semantics of consumers' perceived value, namely the participants' evaluation after purchasing and using a furniture product, in which a Likert five-level and fifty-equal-part scale was transformed into a fuzzy scale (strong disagree: 0.1-1; disagree: 1.1-2; neither agree nor disagree: 2.1-3; agree: 3.1-4; strongly agree: 4.15) to measure consumers' recognition of and opinions about product design features as well as the fuzzy semantics of the consumers' perceived value.

\section{Questionnaire survey design}

Based on Parasuraman, Zeithaml, and Berry's (1988) SERVQUAL scale, the questionnaire was designed in this study, as shown in Tables 1 and 2. The dimensions for the fuzzy semantics of consumers' perceived value on the features of furniture product design were respectively "strongly agree," "more agree," "agree," “disagree," and "strongly disagree." The first part of the questionnaire draft was of basic demographic statistics, including gender, age, education background, occupation, and monthly income. The second part (Table 1) was for the opinions and evaluation on product design features, respectively distinction, integration, and interaction. The third part (Table 2) was the evaluation questions about the participants' actual experience in purchasing and using furniture products.

\section{Research result statistics and analysis}

\section{Descriptive statistic results}

The structure of the samples in this study is displayed in Table 3. All of the 723 participants from different areas in Taiwan recognized the features of furniture product design. In terms of gender, male participants accounted for $45.2 \%$ whereas female participants accounted for $54.8 \%$. In terms of age, "20 to 29 years old" accounted for $23.4 \%$, which was the highest, whereas "50 to 60 years old" accounted for $10.1 \%$, which was the lowest. As for education background, "college/university" accounted for $39.8 \%$, which was the highest, while "postgraduate institute or higher" accounted for $7.7 \%$, which was the lowest. In terms of income, NT\$30,000 to 39,999 " accounted for $18.8 \%$, which was the highest, whereas "NT\$ 60,000 or higher" accounted for $11.1 \%$, which was the lowest. 
Table 1: Opinions and evaluation on product design features, including distinction, integration, and interaction

The second part of the questionnaire: This part is for your opinions and evaluation on product design features, including distinction, integration, and interaction. Please answer the following questions according to your subjective feelings. "Strongly Agree" is Level 5, and the score ranges from 4.1 to 5, totally 10 equal portions. "More Agree" is Level 4, and the score ranges from 3.1 to 4, totally 10 equal portions. "Agree" is Level 3, and the score ranges from 2.1 to 3, totally 10 equal portions, "Disagree" is Level 2, and the score ranges from 1.1 to 2 , totally 10 equal portions. "Strongly Disagree" is Level 1, and the score ranges from 0.1 to 1 , totally 10 equal portions. In total, there are 50 equal portions. Please score the level you select according to your opinions and evaluation. In the display of fuzzy semantic scale, 4.8 and 4.4, for instance, both belong to Level 5, but they differentiate the score more delicately.

\begin{tabular}{|c|c|c|c|c|c|c|}
\hline \multicolumn{2}{|r|}{ Questionnaire Items on Product Design Features } & $\mathbf{L 5}$ & L 4 & L 3 & $\mathbf{L} \mathbf{2}$ & $\mathbf{L} 1$ \\
\hline item 11. & I pay attention to the size of a furniture product. & & & & & \\
\hline item 12. & A beautiful furniture product will increase my purchase intention. & & & & & \\
\hline item 13. & The color of a furniture product attracts me first. & & & & & \\
\hline item 14. & $\begin{array}{l}\text { I always consider the texture of a furniture product, namely if it feels good when I touch } \\
\text { it. }\end{array}$ & & & & & \\
\hline item 15. & The color combination of a furniture product makes me happy when I use it. & & & & & \\
\hline item 16. & The design of a furniture product should provide users with the ease of use. & & & & & \\
\hline item 17. & I like to use a furniture product with a simple structure but multiple functions. & & & & & \\
\hline item 18 . & $\begin{array}{l}\text { When I use a furniture product, it will bring me comfort and enable me to enjoy } \\
\text { wonderful responses and interaction. }\end{array}$ & & & & & \\
\hline item 19. & $\begin{array}{l}\text { When using a furniture product, I can operate it easily with my intuition, and I do not } \\
\text { need any additional explanation. }\end{array}$ & & & & & \\
\hline Item 20. & I will consider the ergonomic design of a furniture product in order to meet my demand. & & & & & \\
\hline
\end{tabular}

Table 2: The evaluation items for the fuzzy semantics of the consumers' perceived value based on your actual experience in purchasing and actually using a furniture product.

The third part of the questionnaire: This part is to evaluate the fuzzy semantics of consumers' perceived value. Please answer the questions subjectively according to your actual experience in purchasing and using furniture products. "Strongly Agree" is Level 5, and the score ranges from 4.1 to 5, totally 10 equal portions. "More Agree" is Level 4, and the score ranges from 3.1 to 4, totally 10 equal portions. "Agree" is Level 3, and the score ranges from 2.1 to 3, totally 10 equal portions, "Disagree" is Level 2, and the score ranges from 1.1 to 2, totally 10 equal portions. "Strongly Disagree" is Level 1, and the score ranges from 0.1 to 1 , totally 10 equal portions. In total, there are 50 equal portions. Please score the level you select according to your opinions and evaluation. In the display of fuzzy semantic scale, 4.8 and 4.4, for instance, both belong to Level 5, but they differentiate the score more delicately.

\begin{tabular}{|c|c|c|c|c|c|c|}
\hline & Questionnaire Items for the Fuzzy Semantics of Consumers' Perceived Value & L5 & L 4 & L 3 & L 2 & L 1 \\
\hline item 21. & $\begin{array}{l}\text { I feel a furniture product is more worth buying when its size is bigger, and the price is } \\
\text { lower. }\end{array}$ & & & & & \\
\hline item 22. & I fell a furniture product is more valuable when I like the appearance and shape. & & & & & \\
\hline item 23. & I feel a furniture product is not worth purchasing when I don't like the color. & & & & & \\
\hline item 24. & I feel a furniture product is not worth purchasing when the materials do not feel good. & & & & & \\
\hline item 25. & $\begin{array}{l}\text { I will feel a furniture product is worth purchasing if the color combination makes me } \\
\text { happy when I use it. }\end{array}$ & & & & & \\
\hline item 26. & $\begin{array}{l}\text { I regret purchasing a furniture product when the design does not bring me any ease of } \\
\text { use. }\end{array}$ & & & & & \\
\hline item 27. & I like to use a furniture product with a simple structure, and I feel it is worth purchasing. & & & & & \\
\hline item 28. & I feel a furniture product is worth purchasing when, intuitively, it is easy to use. & & & & & \\
\hline item 29. & $\begin{array}{l}\text { I feel more like purchasing an ergonomically designed furniture product which meets } \\
\text { my demand. }\end{array}$ & & & & & \\
\hline
\end{tabular}


Table 3: The background statistics of the samples

\begin{tabular}{|c|c|c|c|}
\hline \multicolumn{2}{|c|}{ Demographic Variables } & \multirow{2}{*}{$\begin{array}{c}\begin{array}{c}\text { Samples } \\
(\mathbf{n}=\mathbf{7 2 3})\end{array} \\
327\end{array}$} & \multirow{2}{*}{$\begin{array}{c}\begin{array}{c}\text { Total Sample } \\
\text { Percentage }\end{array} \\
45.2\end{array}$} \\
\hline Condo & Male & & \\
\hline Gender & Female & 396 & 54.8 \\
\hline \multirow{6}{*}{ Age } & $\begin{array}{l}\text { Under } 20 \text { years } \\
\text { old }\end{array}$ & 143 & 19.8 \\
\hline & 20-29 years old & 169 & 23.4 \\
\hline & 30-39 years old & 90 & 12.4 \\
\hline & $40-49$ years old & 160 & 22.1 \\
\hline & $50-60$ years old & 73 & 10.1 \\
\hline & $\begin{array}{l}\text { Above } 60 \text { years } \\
\text { old }\end{array}$ & 88 & 12.2 \\
\hline \multirow{5}{*}{$\begin{array}{l}\text { Education } \\
\text { Background }\end{array}$} & $\begin{array}{l}\text { Junior high school } \\
\text { or lower }\end{array}$ & 97 & 13.4 \\
\hline & $\begin{array}{l}\text { Senior/vocational } \\
\text { high schools }\end{array}$ & 161 & 22.3 \\
\hline & Junior college & 121 & 16.7 \\
\hline & College/university & 288 & 39.8 \\
\hline & $\begin{array}{l}\text { Postgraduate } \\
\text { institute or higher }\end{array}$ & 56 & 7.7 \\
\hline \multirow{6}{*}{ Income } & Under NT $\$ 20,000$ & 134 & 18.5 \\
\hline & $\begin{array}{l}\text { NT\$20,000- } \\
29,999\end{array}$ & 121 & 16.7 \\
\hline & $\begin{array}{l}\text { NT\$30,000- } \\
39,999\end{array}$ & 136 & 18.8 \\
\hline & $\begin{array}{l}\text { NT\$40,000- } \\
49,999\end{array}$ & 114 & 15.8 \\
\hline & $\begin{array}{l}\text { NT\$50,000- } \\
59,999\end{array}$ & 138 & 19.1 \\
\hline & $\begin{array}{l}\text { NT } \$ 60,000 \text { or } \\
\text { higher }\end{array}$ & 80 & 11.1 \\
\hline
\end{tabular}

\section{Reliability and validity}

The second part of the questionnaire was about the participants' opinions and evaluation on the features of furniture product design, respectively distinction, integration, and interaction. It is shown in Table 4 that the Cronbach's $\alpha$ value was 0.942 , higher than 0.7 , indicating that there was a certain degree of content validity. The third part of the questionnaire was about the participants' purchase and post-use evaluation on furniture products. The Cronbach's $\alpha$ value was 0.927 , higher than 0.7, indicating that there was a certain degree of content validity.

\section{Table 4: Questionnaire reliability analysis}

\begin{tabular}{l|c}
\hline Item & Cronbach's $\boldsymbol{\alpha}$ Value \\
\hline The features of furniture product design & .942 \\
\hline $\begin{array}{l}\text { The fuzzy semantics of consumers' } \\
\text { perceived value }\end{array}$ & .927 \\
\hline
\end{tabular}

The descriptive statistics of the fuzzy semantic questionnaire

The second part of the questionnaire was about the influence of the features of furniture product design, respectively distinction, integration, and interaction, on consumers' fuzzy semantics. As shown in Table 5, item 17 "I like to use a furniture product with a simple structure but multiple functions." was the most significant, and the fuzzy semantic mean was 4.4205. Meanwhile, item 11 "I pay attention to the size of a furniture product." was the least significant, and the fuzzy semantic mean was 3.8562 .

Table 5: The descriptive statistics of the second part of the fuzzy semantic questionnaire

\begin{tabular}{lccc}
\hline & \multicolumn{3}{c}{ Fuzzy } \\
& Nemantic & \\
Mean & Std. Deviation \\
\hline item11 & 723 & 3.8562 & .79736 \\
item12 & 723 & 4.0553 & .80836 \\
item13 & 723 & 4.1245 & .83284 \\
item14 & 723 & 4.0858 & .80052 \\
item15 & 723 & 4.1452 & .69997 \\
item16 & 723 & 4.2254 & .72952 \\
item17 & 723 & 4.4205 & .73701 \\
item18 & 723 & 4.3430 & .77614 \\
item19 & 723 & 4.1411 & .73648 \\
item110 & 723 & 4.2282 & .72102 \\
\hline
\end{tabular}

The third part of the questionnaire was about the influence of the features of furniture product design, respectively distinction, integration, and interaction, on consumers' fuzzy semantics, as shown in Table 6 . The fuzzy semantics of item 17 "I like to use a furniture product with a simple structure but multiple functions." was the highest, and the fuzzy semantic mean was 4.4205, as shown in Figure 5. The fuzzy membership function $\operatorname{was} u(x): 1=(4.42-4.0)$ : (5-4) and the obtained fuzzy membership function was that $u(x)=0.42$. It was thus known that the questionnaire value was between "Strongly Agree" and "More Agree," and the fuzziness was .42 , indicating that the participants more agreed but did not strongly agree on that consumers like to use a furniture product with a simple structure but multiple functions. As shown by Figure 6, the fuzzy semantics of item 11 "I pay attention to the size of a furniture product." was the lowest, and the fuzzy semantic mean was 3.8562 . The fuzzy membership function was $u(x)=.8562$, as indicated by Figure 6 . It is thus known that the questionnaire value was between "Agree" and "More Agree," and the fuzziness was.8562, indicating that the participants tended to more agree on that consumers pay attention to the size of a furniture product. 


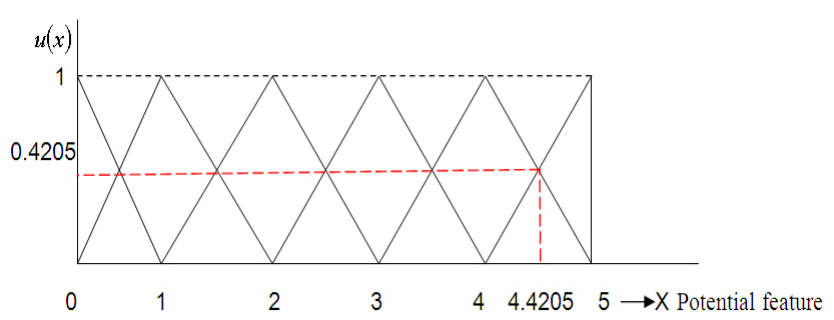

Figure 5: The membership function figure of five-level semantic variables

Table 6: The descriptive statistics of the third part of the fuzzy semantic questionnaire

\begin{tabular}{lccc}
\hline & \multicolumn{3}{c}{ Fuzzy } \\
& Nemantic & \\
& Mean & Std. Deviation \\
\hline item21 & 723 & 3.2600 & .74907 \\
item22 & 723 & 4.2669 & .67962 \\
item23 & 723 & 4.0456 & .69972 \\
item24 & 723 & 4.2517 & .77369 \\
item25 & 723 & 3.8022 & .74870 \\
item26 & 723 & 4.2974 & .58734 \\
item27 & 723 & 4.2033 & .64794 \\
item28 & 723 & 3.8783 & .80105 \\
item29 & 723 & 4.2905 & .63704 \\
\hline
\end{tabular}

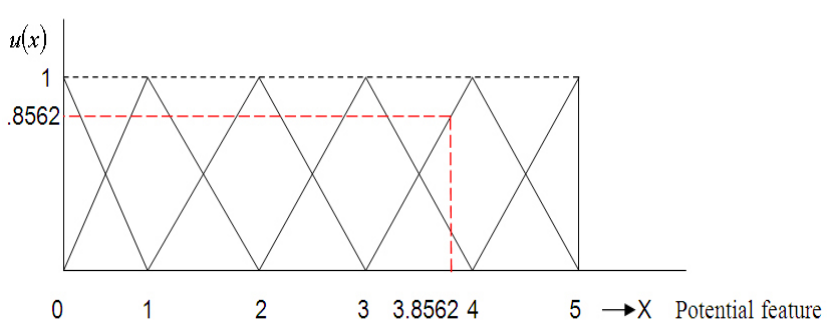

Figure 6: The membership function figure of five-level semantic variables

The influence of the features of furniture product design, namely distinction, integration, and interaction, on the fuzzy semantics of consumers' perceived value.

In this study, the Pearson Chi-square test was applied to examine the influence of different features of furniture product design on the fuzzy semantics of consumers' perceived value. According to the correlation test of the features of furniture product design, respectively distinction, integration, and interaction, as well as the fuzzy semantics of consumers' perceived value, the correlation coefficient of distinction, integration, interaction, and the fuzzy semantics of consumers' perceived value $\mathrm{p}=.0000<.05$. Therefore, there was significant influence among them, and $\mathrm{H}_{1}-1, \mathrm{H}_{1}-2$, and $\mathrm{H}_{1}-$ 3 were supported. Distinction, one feature of furniture product design, thus influenced the fuzzy semantics of consumers' perceived value, as displayed by Table 7 . Integration, one feature of furniture product design, thus influenced the fuzzy semantics of consumers' perceived value, as displayed by Table 8 . Interaction, one feature of furniture product design, thus influenced the fuzzy semantics of consumers' perceived value, as displayed by Table 9. To summarize the aforementioned, H1 was supported in this study.

Table 7: The influence of distinction on the fuzzy semantics of consumers' perceived value

\begin{tabular}{lccc}
\hline Variable & \multicolumn{1}{c}{$\boldsymbol{X}^{2}$} & $\boldsymbol{d} \boldsymbol{f}$ & $\boldsymbol{p}$ \\
\hline $\begin{array}{l}\text { Distinction * } \\
\text { item 21 }\end{array}$ & $1057.869(\mathrm{a})$ & 24 & $.000^{*}$ \\
$\begin{array}{l}\text { Distinction * } \\
\text { item 22 }\end{array}$ & 446.912 & 16 & $.000^{*}$ \\
$\begin{array}{l}\text { Distinction * } \\
\text { item 23 }\end{array}$ & 781.445 & 16 & $.000^{*}$ \\
$\begin{array}{l}\text { Distinction * } \\
\text { item 24 }\end{array}$ & 480.925 & 16 & $.000^{*}$ \\
$\begin{array}{l}\text { Distinction * } \\
\text { item25 }\end{array}$ & 897.600 & 24 & $.000^{*}$ \\
$\begin{array}{l}\text { Distinction * } \\
\text { item26 }\end{array}$ & 387.748 & 16 & $.000^{*}$ \\
$\begin{array}{l}\text { Distinction * } \\
\text { item27 } \\
\text { Distinction * }\end{array}$ & 435.510 & 16 & $.000^{*}$ \\
item28 \\
$\begin{array}{l}\text { Distinction * } \\
\text { item29 }\end{array}$
\end{tabular}

Table 8: The influence of integration on the fuzzy semantics of consumer's perceived value

\begin{tabular}{lccc}
\hline Variable & \multicolumn{1}{c}{$\boldsymbol{X}^{\mathbf{2}}$} & $\boldsymbol{d} \boldsymbol{f}$ & $\boldsymbol{p}$ \\
\hline $\begin{array}{l}\text { Integration * } \\
\text { item21 }\end{array}$ & 548.679 & 15 & $.000^{*}$ \\
$\begin{array}{l}\text { Integration * } \\
\text { item22 }\end{array}$ & 542.647 & 10 & $.000^{*}$ \\
$\begin{array}{l}\text { Integration * } \\
\text { item23 }\end{array}$ & 457.984 & 10 & $.000^{*}$ \\
$\begin{array}{l}\text { Integration * } \\
\text { item24 }\end{array}$ & 350.145 & 10 & $.000^{*}$ \\
$\begin{array}{l}\text { Integration * } \\
\text { item25 }\end{array}$ & 767.132 & 15 & $.000^{*}$ \\
$\begin{array}{l}\text { Integration * } \\
\text { item26 }\end{array}$ & 506.072 & 10 & $.000^{*}$ \\
$\begin{array}{l}\text { Integration * } \\
\text { item27 }\end{array}$ & 464.967 & 10 & $.000^{*}$ \\
$\begin{array}{l}\text { Integration * } \\
\text { item28 }\end{array}$ & 200.558 & 10 & $.000^{*}$ \\
$\begin{array}{l}\text { Integration * } \\
\text { item29 }\end{array}$ & 446.510 & 10 & $.000^{*}$ \\
\hline
\end{tabular}


Table 9: The influence of interaction on the fuzzy semantics of consumers' perceived value

\begin{tabular}{lccc}
\hline Variable & $\boldsymbol{X}^{\mathbf{2}}$ & $\boldsymbol{d} \boldsymbol{f}$ & $\boldsymbol{p}$ \\
\hline Interaction * item21 & 538.894 & 18 & $.000^{*}$ \\
Interaction * item22 & 455.094 & 12 & $.000^{*}$ \\
Interaction * item23 & 603.542 & 12 & $.000^{*}$ \\
Interaction * item24 & 283.367 & 12 & $.000^{*}$ \\
Interaction * item25 & 771.996 & 18 & $.000^{*}$ \\
Interaction * item26 & 308.661 & 12 & $.000^{*}$ \\
Interaction * item27 & 762.491 & 12 & $.000^{*}$ \\
Interaction * item28 & 578.711 & 12 & $.000^{*}$ \\
Interaction * item29 & 756.577 & 12 & $.000^{*}$ \\
\hline
\end{tabular}

\section{Linear regression analysis}

The linear regression analysis was employed to analyze the correlation between the features of furniture product design and the fuzzy semantics of consumers' perceived value in order to establish a mathematical function relationship by which the variables of perceived value were predicted. (ti 1 , ti 2, ti $_{3}$ ), the features of product design, namely distinction, integration, and interaction, were regarded as independent variables, and (Y), the fuzzy semantic of consumers' perceived value was regarded as the dependent variable to predict the fuzzy semantics of consumers' perceived value as time changed. The time series regression model was obtained as follows:

$\mathrm{Yi}=\mathrm{a}+\mathrm{b}_{1} \mathrm{ti}_{1}+\mathrm{b}_{2} \mathrm{ti}_{2}+\mathrm{b}_{3} \mathrm{ti}_{3}$

in which $\mathrm{Y}$ is the prediction of the fuzzy semantics of consumers' perceived value; a is additional constant; ti $_{1}$ (distinction), ti 2 (integration), and ti 3 (interaction) are predictors; $\mathrm{b}_{1}, \mathrm{~b}_{2}$, and $\mathrm{b}_{3}$ are linear slope ratios.

A linear regression model was used as the consumer prediction equation and transformed into "predicted perceived value $=\mathrm{a}+\mathrm{b}_{1} *$ Distinction $+\mathrm{b}_{2} *$ Integration $+\mathrm{b}$

3 * Interaction."

In this study, a multiple linear regression model was employed to predict the relational equation for the influence of the features of furniture product design on the fuzzy semantics of consumers' perceived value (as shown in Tables 10, 11, and 12). In this multiple linear regression model, there were three predictors, respectively distinction, integration, and interaction, which were significantly related to the fuzzy semantics of consumers' perceived value. Moreover, $\mathrm{R}^{2}=.990$; adjustedR ${ }^{2}=.989 ; \mathrm{F}$ $(3,719)=22658.037 ; p=.000$. The multiple linear regression equation obtained in this study was that "predicted perceived value $=.14+.48$ distinction +.283 integration +.230 interaction." Figure 7 is the scatter plot for the fuzzy semantics of consumers' perceived value predicted by the features of furniture product design through a linear regression analysis. According to figure 7 , the perceived values centered between 3.60 and 4.00, indicating that the participants all agreed on the fuzzy semantics of the perceived value of each item in the questionnaire.

Table 10: The model summary of the linear regression analysis

\begin{tabular}{cclc}
\hline & & $\mathbf{R}$ & \\
Model & $\mathbf{R}$ & Square & Adjusted R Square \\
\hline 1 & $.995(\mathrm{a})$ & .990 & .989 \\
\hline $\begin{array}{l}\text { a Predictors: (Constant), interaction, distinction, and integration } \\
\text { b Dependent Variable: perceived value }\end{array}$
\end{tabular}

Table 11: The ANOVA of the linear regression analysis

\begin{tabular}{llcccc}
\hline & \multicolumn{5}{c}{ Mean } \\
Model & & df & Square & F & Sig. \\
\hline 1 & Regression & 3 & 37.271 & 22658.037 & $.000(\mathrm{a})$ \\
& Residual & 719 & .002 & & \\
& Total & 722 & & & \\
\hline a Predictors: (Constant), interaction, distinction, and integration \\
b Dependent Variable: perceived value
\end{tabular}

Table 12: The model summary of the linear regression analysis

\begin{tabular}{|c|c|c|c|c|c|c|}
\hline Model & & \multicolumn{2}{|c|}{$\begin{array}{c}\text { Unstandardized } \\
\text { Coefficients }\end{array}$} & $\begin{array}{c}\text { Standardized } \\
\text { Coefficients }\end{array}$ & \multirow[t]{2}{*}{$\mathbf{t}$} & \multirow[t]{2}{*}{ Sig. } \\
\hline \multirow{6}{*}{1} & & & Std. & & & \\
\hline & & B & Error & Beta & & \\
\hline & (Constant) & .014 & .016 & & .867 & .386 \\
\hline & Distinction & .482 & .003 & .628 & 145.464 & .000 \\
\hline & Integration & .283 & .005 & .301 & 57.642 & .000 \\
\hline & Interaction & .230 & .004 & .281 & 54.419 & .000 \\
\hline
\end{tabular}

a Dependent Variable: perceived value

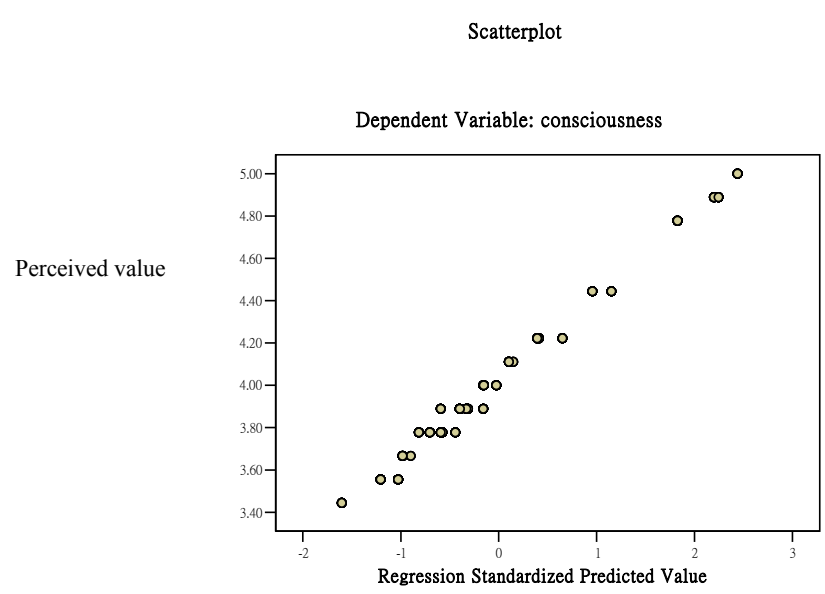

Figure 7: The scatter plot for the fuzzy semantics of consumer's perceived value predicted by the product design features through the linear regression analysis Independent samples T-test

The Independent Samples T-Test was employed to examine and analyze the differences between different 
genders in terms of the fuzzy semantics of consumers' perceived value. The result reached significant variation, as shown in Tables 13 and 14, which indicates that consumers with different genders had similar opinions about the features of furniture product design, respectively distinction, integration, and interaction. The research data proved that the fuzzy semantics of the perceived values of the male and female participants were similar, in which $\mathrm{t}$ (721) $=3.108$ and $p=.002$. The hypothesis of $\mathrm{H}_{2}-1$ was thus supported.

Table 13: The group statistics for the influence of the features of furniture product design on the fuzzy semantics of the perceived values of consumers with different genders

\begin{tabular}{|c|c|c|c|c|c|}
\hline & Gender & $\mathbf{N}$ & Mean & $\begin{array}{c}\text { Std. } \\
\text { Deviation }\end{array}$ & $\begin{array}{c}\text { Std. Error } \\
\text { Mean }\end{array}$ \\
\hline \multirow[t]{2}{*}{$\begin{array}{l}\text { Perceived } \\
\text { value }\end{array}$} & male & 327 & 4.0829 & .41482 & .02294 \\
\hline & female & 396 & 3.9916 & .37452 & .01882 \\
\hline
\end{tabular}

The influence of the features of furniture product design on the fuzzy semantics of the perceived values of consumers with different genders was analyzed. According to Table $14, \mathrm{t}(721)=3.108$, and $p=.002$. The result reached significant variation, namely that the features of furniture product design resulted in a significant difference between the fuzzy semantics of the perceived values of consumers with different genders. The hypothesis of $\mathrm{H}_{2}-1$ was thus supported.

Table 14: The Independent Samples Test for the difference between the fuzzy semantics of the perceived value of consumers with different genders by the features of furniture product design

\begin{tabular}{|c|c|c|c|c|c|c|}
\hline & & \multicolumn{2}{|c|}{$\begin{array}{c}\text { Levene's } \\
\text { Test for } \\
\text { Equality of } \\
\text { Variances } \\
\end{array}$} & \multicolumn{3}{|c|}{$\begin{array}{c}\text { t-test for Equality of } \\
\text { Means } \\
\end{array}$} \\
\hline & & $\mathbf{F}$ & Sig. & $\mathbf{t}$ & df & $\begin{array}{c}\text { Sig. } \\
(2- \\
\text { tailed) } \\
\end{array}$ \\
\hline \multirow[t]{2}{*}{$\begin{array}{l}\text { Perceived } \\
\text { value }\end{array}$} & $\begin{array}{l}\text { Equal } \\
\text { variances } \\
\text { assumed }\end{array}$ & 3.241 & .072 & 3.108 & 721 & .002 \\
\hline & $\begin{array}{l}\text { Equal } \\
\text { variances not } \\
\text { assumed }\end{array}$ & & & 3.078 & 664.196 & .002 \\
\hline
\end{tabular}

The One-way ANOVA was employed to analyze the influence of age on the fuzzy semantics of consumers' perceived value. According to Table 15, F (5, 717) $=25.836$, and $p=.000<0.05$. The result reached significant variation, indicating that the consumers perceived significantly different values from the features of furniture product design, respectively distinction, integration, and interaction. The hypothesis of $\mathrm{H}_{2}-2$ was hence supported.

The One-way ANOVA was used to analyze the relationship between consumers' education backgrounds and the fuzzy semantics of their perceived value. According to Table 16, F $(5,717)=5.934$ to 195.250 from item 21 to item 29 . In addition, there were totally nine $p$ values which were $.000<0.05$. The analysis result reached significant variation. It is obvious in Table 3 that the consumers with the education background of "postgraduate institute or higher" valued the features of furniture product design the most whereas the consumers with the education background of "senior/vocational high schools" and "junior high school or lower" valued it the least, indicating that the consumers with high education backgrounds attached great importance to the features of furniture product design. The hypothesis of $\mathrm{H}_{2}-3$ was thus supported in this study.

Table 15: The ANOVA for the influence of the features of furniture product design on the fuzzy semantics of the perceived value of consumers with different ages

\begin{tabular}{|c|c|c|c|c|}
\hline & & df & $\mathbf{F}$ & Sig. \\
\hline \multirow[t]{3}{*}{ item 21} & $\begin{array}{l}\text { Between } \\
\text { Groups }\end{array}$ & 5 & 25.836 & .000 \\
\hline & Within Groups & 717 & & \\
\hline & Total & 722 & & \\
\hline \multirow[t]{3}{*}{ item 22} & $\begin{array}{l}\text { Between } \\
\text { Groups }\end{array}$ & 5 & 75.262 & .000 \\
\hline & Within Groups & 717 & & \\
\hline & Total & 722 & & \\
\hline \multirow[t]{3}{*}{ item 23} & $\begin{array}{l}\text { Between } \\
\text { Groups }\end{array}$ & 5 & 21.726 & .000 \\
\hline & Within Groups & 717 & & \\
\hline & Total & 722 & & \\
\hline \multirow[t]{3}{*}{ item24 } & $\begin{array}{l}\text { Between } \\
\text { Groups }\end{array}$ & 5 & 15.815 & .000 \\
\hline & Within Groups & 717 & & \\
\hline & Total & 722 & & \\
\hline \multirow[t]{3}{*}{ item 25} & $\begin{array}{l}\text { Between } \\
\text { Groups }\end{array}$ & 5 & 41.641 & .000 \\
\hline & Within Groups & 717 & & \\
\hline & Total & 722 & & \\
\hline \multirow[t]{3}{*}{ item 26} & $\begin{array}{l}\text { Between } \\
\text { Groups }\end{array}$ & 5 & 43.405 & .000 \\
\hline & Within Groups & 717 & & \\
\hline & Total & 722 & & \\
\hline \multirow[t]{3}{*}{ item 27} & $\begin{array}{l}\text { Between } \\
\text { Groups }\end{array}$ & 5 & 86.432 & .000 \\
\hline & Within Groups & 717 & & \\
\hline & Total & 722 & & \\
\hline \multirow[t]{3}{*}{ item 28} & $\begin{array}{l}\text { Between } \\
\text { Groups }\end{array}$ & 5 & 103.707 & .000 \\
\hline & Within Groups & 717 & & \\
\hline & Total & 722 & & \\
\hline \multirow[t]{3}{*}{ item29 } & $\begin{array}{l}\text { Between } \\
\text { Groups }\end{array}$ & 5 & 25.175 & .000 \\
\hline & Within Groups & 717 & & \\
\hline & Total & 722 & & \\
\hline
\end{tabular}


Table 16: The ANOVA for the influence of the features of furniture product design on the fuzzy semantics of the perceived values of consumers with different education backgrounds

\begin{tabular}{|c|c|c|c|c|}
\hline & & df & $\mathbf{F}$ & Sig. \\
\hline \multirow[t]{3}{*}{ item 21} & $\begin{array}{l}\text { Between } \\
\text { Groups }\end{array}$ & 4 & \multirow[t]{3}{*}{195.250} & \multirow[t]{3}{*}{.000} \\
\hline & Within Groups & 718 & & \\
\hline & Total & 722 & & \\
\hline \multirow[t]{3}{*}{ item 22} & Between & 4 & \multirow[t]{3}{*}{40.277} & \multirow[t]{3}{*}{.000} \\
\hline & Within Groups & 718 & & \\
\hline & Total & 722 & & \\
\hline \multirow[t]{3}{*}{ item 23} & Between & 4 & \multirow[t]{3}{*}{61.473} & \multirow[t]{3}{*}{.000} \\
\hline & Within Groups & 718 & & \\
\hline & Total & 722 & & \\
\hline \multirow[t]{3}{*}{ item 24} & Between & 4 & \multirow[t]{3}{*}{18.844} & \multirow[t]{3}{*}{.000} \\
\hline & Within Groups & 718 & & \\
\hline & Total & 722 & & \\
\hline \multirow[t]{4}{*}{ item 25} & Between & 4 & \multirow{4}{*}{22.697} & \multirow{4}{*}{.000} \\
\hline & Groups & 4 & & \\
\hline & Within Groups & 718 & & \\
\hline & Total & 722 & & \\
\hline \multirow[t]{4}{*}{ item 26} & Between & 4 & \multirow{4}{*}{49.199} & \multirow{4}{*}{.000} \\
\hline & Groups & & & \\
\hline & Within Groups & 718 & & \\
\hline & Total & 722 & & \\
\hline \multirow[t]{4}{*}{ item 27} & Between & 4 & \multirow{4}{*}{38.131} & \multirow{4}{*}{.000} \\
\hline & Groups & & & \\
\hline & Within Groups & 718 & & \\
\hline & Total & 722 & & \\
\hline \multirow[t]{4}{*}{ item 28} & Between & 4 & \multirow{4}{*}{62.686} & \multirow{4}{*}{.000} \\
\hline & Groups & & & \\
\hline & Within Groups & 718 & & \\
\hline & Total & 722 & & \\
\hline \multirow[t]{4}{*}{ item 29} & Between & 4 & \multirow{4}{*}{5.934} & \multirow{4}{*}{.000} \\
\hline & Groups & & & \\
\hline & Within Groups & 718 & & \\
\hline & Total & 722 & & \\
\hline
\end{tabular}

The One-way ANOVA was used to analyze the relationship between consumers' incomes and the fuzzy semantics of their perceived value. According to Table 17, F ( 5,717 ) $=5.934$ to 195.250 from item 21 to item29. Furthermore, there were totally nine $p$ values which were $.000<0.05$. The analysis result reached significant variation, indicating that the consumers with different incomes perceived significantly different values from the features of furniture product design, respectively distinction, integration, and interaction. The hypothesis of $\mathrm{H}_{2}-4$ was thus supported in this study.
Table 17: The ANOVA for the influence of the features of furniture product design on the fuzzy semantics of the perceived values of consumers with different incomes

\begin{tabular}{|c|c|c|c|c|}
\hline & & df & $\mathbf{F}$ & Sig. \\
\hline \multirow[t]{4}{*}{ item 21} & Between & 5 & \multirow{4}{*}{71.456} & \multirow{4}{*}{.000} \\
\hline & Groups & $J$ & & \\
\hline & Within Groups & 717 & & \\
\hline & Total & 722 & & \\
\hline \multirow[t]{4}{*}{ item 22} & Between & & \multirow{4}{*}{21.345} & \multirow{4}{*}{.000} \\
\hline & Groups & 5 & & \\
\hline & Within Groups & 717 & & \\
\hline & Total & 722 & & \\
\hline \multirow[t]{4}{*}{ item 23} & Between & 5 & \multirow{4}{*}{7.731} & \multirow{4}{*}{.000} \\
\hline & Groups & J & & \\
\hline & Within Groups & 717 & & \\
\hline & Total & 722 & & \\
\hline \multirow[t]{4}{*}{ item 24} & Between & 5 & \multirow{4}{*}{26.926} & \multirow{4}{*}{.000} \\
\hline & Groups & J & & \\
\hline & Within Groups & 717 & & \\
\hline & Total & 722 & & \\
\hline \multirow[t]{4}{*}{ item 25} & Between & 5 & \multirow{4}{*}{5.667} & \multirow{4}{*}{.000} \\
\hline & Groups & J & & \\
\hline & Within Groups & 717 & & \\
\hline & Total & 722 & & \\
\hline \multirow[t]{4}{*}{ item 26} & Between & 5 & \multirow{4}{*}{39.491} & \multirow{4}{*}{.000} \\
\hline & Groups & J & & \\
\hline & Within Groups & 717 & & \\
\hline & Total & 722 & & \\
\hline \multirow[t]{4}{*}{ item 27} & Between & 5 & \multirow{4}{*}{46.851} & \multirow{4}{*}{.00} \\
\hline & Groups & $J$ & & \\
\hline & Within Groups & 717 & & \\
\hline & Total & 722 & & \\
\hline \multirow[t]{4}{*}{ item 28} & Between & 5 & \multirow{4}{*}{54.787} & \multirow{4}{*}{.00} \\
\hline & Groups & $J$ & & \\
\hline & Within Groups & 717 & & \\
\hline & Total & 722 & & \\
\hline \multirow[t]{4}{*}{ item 29} & Between & 5 & \multirow{4}{*}{6.988} & \multirow{4}{*}{.000} \\
\hline & Groups & J & & \\
\hline & Within Groups & 717 & & \\
\hline & Total & 722 & & \\
\hline
\end{tabular}

\section{Conclusion and suggestion}

The environment for corporate management changes rapidly nowadays. Therefore, enterprises strive to understand consumers' demand for products, develop customer-oriented products, and increase consumers' purchase intention through increasing customers' perceived value of products in order to achieve their management goals and enhance their cooperate performance and market competitiveness. The research result was expected to be a reference of product designers or developers to new product design and development and provide help in the stages of planning and promoting product design. The relational model of the 
features of furniture product design and the fuzzy semantics of consumers' perceived value was investigated in this study. The research result is detailed as follows:

1. A significant correlation existed between the three features of furniture product design, namely distinction, integration, and interaction, as well as the fuzzy semantics of consumers' perceived value. It indicates that when using furniture products, the consumers all thought that the features of furniture product design, respectively distinction, integration, and interaction, as well as the fuzzy semantics of consumers' perceived value were positively correlated.

2. The fuzzy semantics of the perceived values of the consumers with different genders significantly varied in terms of the features of furniture product design, respectively distinction, integration, and interaction. This indicates that furniture designers should consider the differences between genders and integrate them into the design process in order to meet consumers' demand.

3. The fuzzy semantics of the perceived values of the consumers with different ages significantly varied in terms of the features of furniture product design, respectively distinction, integration, and interaction. This indicates that furniture designers should consider the influence of different ages on consumers' perceived value in order to meet consumers' demand.

4. The fuzzy semantics of the perceived values of the consumers with different education backgrounds significantly varied in terms of the features of furniture product design, respectively distinction, integration, and interaction. The consumers with the education background of "postgraduate institute or higher" valued the features of furniture product design the most whereas the consumers with education background of "senior/vocational high school" and "junior high school or lower" valued the features of furniture product design the least. It indicates that the consumers with high education backgrounds attached great importance to the features of furniture product design. Hence, furniture designers and manufacturers should consider the differences between the values perceived by consumers with different education backgrounds.

5. The fuzzy semantics of the perceived values of the consumers with different incomes significantly varied in terms of the features of furniture product design, respectively distinction, integration, and interaction. It indicates that the consumers with difference incomes had different opinions about the features of furniture product design, so furniture designers and manufactures should consider the differences between the values perceived by consumers with different incomes.

In summary, it is suggested that when designing and developing new products, product designers should integrate distinction, integration, and interaction, which were the features of furniture product design that the consumers all recognized, into the process of product design, so that consumers' perceived value will be increased, and the corporate performance in new product design and development will be further enhanced.

This research model can be used as a basis by furniture designers and manufacturers to evaluate the relationship between the features of furniture product design and the fuzzy semantics of consumers' perceived value when developing and designing products, so that consumers' perceived value will be improved in the development and design, and further, consumers' demand will be satisfied, and their purchase intention will be advanced.

\section{References}

Adner. R \& Levinthal, D. 2001. 'Demand heterogeneity and technology evolution: Implications for product and process innovation', Management Science, 47(5): 611-628.

Bowen, J., Lai, R. \& Bahler, D. 1992. 'Fuzzy semantics and fuzzy constraint networks', In IEEE International Conference on Fuzzy Systems, San Diago 8 - 12 Mrt 1992, p.p.1009-1016.

Carlsson, C. \& Fuller, F. 2000. 'Benchmarking in linguistic importance weighted aggregations', Fuzzy Sets and Systems, 114: 35-41.

Chen, S.J. \& Hwang, C.L. 1992. Fuzzy multiple attribute decision making - methods and applications. Germany: Springer-Verlag.

Chen, Y.H., Wang, W.J. \& Chiu, C.H. 2000. 'New estimation method for the membership values in fuzzy sets', Fuzzy Sets and Systems, 112: 521-525.

Chen, Y.T. 2010. 'The relationship between brand association and product features on mobile phones'. Masters dissertation, National Taiwan University of Science and Technology, Taipei, Taiwan.

Chen, Z. \& Dubinsky, A.J. 2003. 'A conceptual model of perceived customer value in e-commerce: A preliminary investigation', Psychology and Marketing, 20(4):323-347.

Chien, C.J. \& Tsai, H.H. 2000. 'Using fuzzy numbers to evaluate perceived service quality', Fuzzy Sets and Systems, 116: $289-300$.

Costs, C.S.L., Maranon, P.P. \& Cabrera, J.A.H. 1994. 'Application of diffuse measurement to the evaluation of psychological structures', Quality and Quanty, 28: 305-313.

Dodds, W.B. \& Monroe, K.B. 1985. 'The effect of brand and price information on subjective product evaluation', Advances in Consumer Research, 12: 85-90.

Engel, J.F., Blackwell, R.D. \& Miniard, P.W. 2001. Consumer behavior. Harcourt Broce Joranovich College Publishers: The Dryden Press. 
Fant, F.L., Pamela, K.C.1992. 'A neural network approach to forecasting financial distress, The Journal of Business Forecasting. Winter :9-12.

Goldberg, D.E. 1989. Genetic algorithms in search, optimization, and machine learning. Reading, MA: Addison-Wesley.

Goumas, M. \& Lygerou, V. 2000. 'An extension of the PROMETHEE method for decision making in fuzzy environments: Ranking of alternative energy exploitation projects', European Journal of Operational Research, 123: 606-613.

Herrera, F., Lopez, E., Mendana, C. \& Rodriguez, M.A. 2001. 'A linguistic decision model for personnel management solved with a linguistic biobjective genetic algorithm', Fuzzy Sets and Systems, 118: 47-64.

Hesketh, B., Pryor, R., Gleitzman, M. \& Hesketh, T. 1988. 'Practical applications and psychometric evaluation of a computerized fuzzy graphic ration scale'. In Zetenyi, T. (ed.). Fuzzy sets in psychology. New York: North-Holland, p.p.425-454.

Hsiao, K.A. \& Chen, P.Y. 2010. 'Cognition and shape features of pleasure images', Journal of Design, 15(2):1-17.

Hsu, T.H. \& Lin, L.C. 2005. 'Fuzzy set theory for building analysis matrixes of travel risk', San Yet-sen Management Review, 13(2): 479-509.

Janikow, C. Z. 1998. 'Fuzzy decision trees: Issues and methods', IEEE Transactions on Systems, Man, and Cybernetics-Part B: Cynernetics, 28(1):1-14.

Kacprzyk, J., Fedrizzi, M. \& Nurmi, H. 1992. 'Group decision making and consensus fuzzy preferences and fuzzy majority', Fuzzy Sets and Systems, 49:21-31.

Kaufmann, A. \& Gupta, M.M. 1991. Introduction to fuzzy arithmetic theory and application. New York: Van Nostrand Reinhold.

Klir, G.J. \& Yuan, B. 1995. Fuzzy sets and fuzzy logic: Theory and applications. Upper Saddle River: Prentice Hall.

Korgaonkar, P.K., Lund, D. \& Price, B. 1985. 'A structuralequations approach toward examination of store attitude and store patronage behavior', Journal of Retailing, 61(2):3960.

Kotler, P. 1998. Marketing management: Analysis, planning, implementation, and control. $9^{\text {th }}$ Edition. PrenticeHall, Inc.

Lin, S.T. 2011. 'A study on the customer perceived value in product design and manufacturing'. Masters dissertation, Shih Chien University, Taipei, Taiwan.
Lin, Y.H. 2003. 'The algorithm of fuzzy linguistic numbers and its comparison of scoring', Journal of National Taichung Teachers College, 17(2): 279-304.

Lin, Y.H. 2004. 'Psychological tests and statistics: Fuzzy semantic differences', Journal of Education Research, 126: 136-138.

Matarazzo, B. \& Munda, G. 2001. 'New approaches for the comparison of L-R fuzzy numbers: A theoretical and operational analysis', Fuzzy Sets and Systems, 118: 407-418.

Nunnally, J.C. 1995. Psychometric theory. $2^{\text {nd }}$ Edition. New York: McGraw-Hill.

Nussbaum, B. 1988. 'Quality in the new style', Smart design, Business Week 11 Apr 1988:102.

Parasuraman, A., Zeithaml, V.A. \& Berry, L.L. 1988. 'SERVQUAL: A multiple-item scale for measuring consumer perceptions of service quality', Journal of Retailing, 64(1): 12-40.

Ravald, A. \& Gronroos, C. 1996. 'The value concept and relationship marketing', European Journal of Marketing, 30: 19-30.

Su, W.K. 2007. 'The effect of product design on customer value - a case study of digital camera'. Masters dissertation, National Chung Cheng University.

Tang, Y.H. 2009. 'Fuzzy theory in innovative product development for conceptual design'. Masters dissertation, Tunghai University, Taichung, Taiwan.

Tsai, C.Y., Chang, P.C. \& Wang, S. J. 2003. 'Applying association-rule techniques and artificial neural networks to product development', Journal of the Chinese Institute of Industrial Engineers, 20(2):101-112.

Voxman, W. 2001. 'Canonical representations of discrete fuzzy numbers', Fuzzy Sets and Systems, 118: 457-466.

Wei, C.C. 2003. 'A research for fuzzy decision making in the initial stage of product design'. Masters dissertation, Da Yeh University, Changhua, Taiwan.

Woodruff, R.B. 1997. 'Customer value: The next source for competitive advantage', Journal of the Academy of Marketing Science, 25(2):139-153.

Wu, T.J. 2010. 'Application of fuzzy theory and multi-choice goal programming on product design'. Masters dissertation, China University of Science and Technology, Taipei, Taiwan.

Wu, W.Y., Hsiao, S.W. \& Kuo, H.P. 2004. 'Fuzzy set theory based decision model for determining market position and developing strategy for hospital service quality', Total Quality Management, 15(4): 439-456. 
Zeithaml, V.A. 1988. 'Consumer perceptions of price and value: A means-end model \& synthesis of evidence', Journal of Marketing, 52(3): 2-22.

Zadeh, L.A. 1965. 'Fuzzy sets', Information and Control, 8: 338-353.

Zedtwitz, M.V. \& Gassmannb, O. 2002. 'Market versus technology drive in R\&D internationalization: Four different patterns of managing research and development', Research Policy, 31:569-588. 